\title{
The Danish Folk High Schools as the Schools for Life - the history, the present and the future
}

\author{
Duńskie uniwersytety ludowe jako szkoty dla życia - historia, \\ czasy wspołczesne i przyszłość
}

Streszczenie: Artykuł został przygotowany przez zespół autorów z Den Frie Lœererskole w Ollerup - niezależnej duńskiej instytucji szkolnictwa wyższego przygotowującej kadry pedagogiczne dla potrzeb tamtejszych wolnych szkół dla dzieci i młodzieży oraz nieformalnej edukacji dorosłych, w tym uniwersytetów ludowych, która na gruncie polskim od wielu lat współpracuje z Kaszubskim Uniwersytetem Ludowym w Wieżycy (stąd w artykule wykorzystano także wydane w Polsce pozycje literatury przedmiotu). Autorzy zaprezentowali główne kierunki przemian, jakie zaszły w roli duńskich uniwersytetów ludowych od czasów II wojny światowej do współczesności, oraz wskazali na perspektywy dalszego rozwoju tych instytucji w Danii i na świecie ze względu na uniwersalizm idei edukacyjnych wyprowadzonych z grundtvigiańskiej koncepcji szkoły dla życia.

Słowa kluczowe: uniwersytety ludowe, wolne szkoły w Danii, nieformalna edukacja dorosłych, koncepcja szkoły dla życia, edukacja dorosłych w Danii.

Summary: This article was prepared by a team of authors from the Den Frie Lererskole (English name: The Independent Academy for Free School Teaching) in Ollerup - Danish independent institution of higher education that prepares teaching staff for free schools for children and youth and non-formal adult education, including Folk High Schools. The Academy cooperates with Kashubian Folk High School in Wieżyca for many years, therefore in the bibliography the reader will find not only the Danish and English but also Polish literature on Folk High Schools. The authors presented the main directions of the changes that have occurred in the role of the Danish Folk High Schools since the World War II to the present day, and pointed to the prospects for further development of these institutions in Denmark and around the world because of the universality of educational ideas derived from the Grundtvigian concept of School for Life. 
Keywords: folk high schools, Danish free schools, non-formal adult education, concept of School for Life, adult education in Denmark.

"Man is not an ape, but a divine experiment" wrote the Danish pastor, author, poet, philosopher, historian, teacher and politician N. F. S. Grundtvig in 1832 in his major work "The Nordic Mythology." When Grundtvig talks of Apes in relation to man we should not, incidentally, imagine it has anything to do with the theory of evolution. Darwin's book "Origin of Species" did not appear until 25 years later. Grundtvig is merely trying to explain what he sees as a crucial difference in quality between ape and man. Apes can only imitate what others have already done. Man, on the other hand, is capable of doing what has to be done!

And what, then, is it that has to be done? Quite frankly, there is no ready answer as to precisely what it is, and we each have to find that out for ourselves. That is what the experiment is all about. It is in that frame you find the Danish Folk high Schools.

The first Folk High School was founded in Rødding, in 1844, inspired by the educational thinking of Grundtvig. Grundtvig identified a growing democratic need in society - a need to enlighten the often both uneducated and poor peasantry. This social group had neither the time nor the money to take a course in further education at a university and needed an alternative opportunity. The aims of the Folk High Schools at that time were to help people qualify as active and engaged members of society, give them the tools to change the political situation from below and be a place to meet across social boarders. Denmark had just gained democracy, which demanded a need for Folk High Schools. In 1892, almost 50 years after the first schools was founded, the Folk High Schools became part of the law. From then on the Schools were subsided by the government, but there were no regulations as to the content of the teaching on the schools.

\section{After the World War II}

The first years after the war were good years for the Folk High Schools, many people wanted to spend a semester at a Folk High School. Nevertheless most of the pupils came from the rural areas, which was where the schools were found as well. Krogerup Højskole was founded in 1946, which was a quite dif- 
ferent school. They were able to get most of their students from the city areas. This is a prosperous period for the Folk High Schools and many schools opened.

\section{The Danish Folk High Schools of the 70s}

Denmark becomes a member of the European Union in 1973, which together with the youth revolt influences the Folk High Schools in Denmark. The young people demand citizenship and democracy on the scheme.

Once again it appeared that concerns about the Folk High Schools' opportunities in the exam-oriented common sense was superfluous. It was not pressure towards a form of teaching that rewarded competency that was the Folk High Schools' real problem in the 70s. Young people tried in large numbers to gain qualifications through further education beyond the compulsory nine years, and growing youth unemployment during the 70s provided a strong incentive to spend the time getting the best possible educational qualifications. Many young people saw modern society's continuing education requirements as unification under a rational domination. They dreamed of freedom without all the institutions, and this dream the Folk High Schools provided a brilliant opportunity to realise, an opportunity denied by other school forms. Educated young people from the city with both 10 and 12 years of schooling behind them went in large numbers to Folk High School to realize their desire for another kind of society. They cast off the old traditions or they sought to create completely new schools that could offer them a significant influence on both the teaching and socializing. In this absence of pre-established requirements and standards it became meaningful to engage in learning.

The Folk High Schools did not feel the pressure from the society on the need to develop competence, but it felt the pressure from a whole generation who wanted to reinvent the world order.

This generation of city people took over many of the Schools; this was a goodbye to the historic ties with the rural communities. The farmers who formerly had been the supporters of the Schools felt themselves to be strangers. Strangers to the values, to the students and to the teachers. From then on the farmers concentrated only on their academic education. 


\section{The Danish Folk High Schools of the 80s}

In the 1980s the Folk High Schools are distributed throughout the Danish countryside, all the way from the predominantly rural west coast of Jutland, the large peninsula that shares a land border with Germany, to the urban milieu of Copenhagen and the far-off island of Bornholm in the North Baltic. The 1988 catalogue of the folk high school secretariat in Copenhagen lists 106 such schools. Close to fifty thousand students in a nation of just over 5 million people will pass through them this year. Many Danes choose to spend at least a part of their summer vacation taking a folk high school course. Some return year after year to the same school. Prospective students in 1987, for example, could choose between the 809 different short courses of one, two, or three weeks' duration, or one of the long courses, which typically take from three to ten months.

What type of person is one likely to encounter at a folk high school in the 80s? A middle-aged Danish farmer, spending a month with easel and canvas, finally surrenders to his lifelong desire to paint. A woman with a sixyear-old son comes to shape clay on a potter's wheel. While she moulds clay on long afternoons, the boy plays soccer, tries his hand with water-colour painting, finds other children with whom to explore a friendly rural environment. Here is a man of thirty who has been unemployed for the past two years; there is a young woman taking a year off from her veterinary studies at the university. There are some who have just finished gymnasium, and others who never finished the eighth grade. Some come in hopes of finding a girlfriend or a boyfriend. Some are trying to kick a drug habit or control a problem with alcohol. Some come only because a social worker has urged them to do so and perhaps conveniently arranged their stay. Some want to see a different part of the country than the one they have always known or have come to escape the devastation of a recent and traumatic divorce. Some don't know what they want or why they have come here. Some will meet a future wife or husband. Some charm everybody and leave without paying all their bills. In truth, all kinds of people come to a Danish folk high school at this time, and they come for all kinds of reasons.

The development in the number of Folk High Schools reaches its highpoint in 1985, with 107 Schools all over the country. In 1970 there were 70 schools, which is almost the same amount as you find today. 


\section{The Danish Folk High School of the 90s}

In the beginning of the 90 s $57 \%$ of pupils were on social security without a job; they were able to spent their time at a Folk High School instead of searching for a job. That possibility disappeared in the middle of the 90s. From then on many Schools changed gradually.

The diversity of the Danish folk high schools in the 1980s and early 1990s is quite extraordinary. There are perhaps half a dozen schools with a radical communist or feminist orientation. There are, on the other hand, at least the same number of schools that teach some particular brand of ultraconservative Christian theology. Side by side with these can be found Folk High Schools that specialize in ecology and biodynamic agriculture, Folk High Schools for athletic instruction, Folk High Schools for instruction in music, and Folk High Schools for various kinds of travel abroad. There are Folk High Schools for the study of foreign languages, Folk High Schools for retired people, and at least one Folk High School for teenagers under the age of eighteen. There are several "Folk High Schools for consciousness development", one of which teaches the Maharishi's transcendental meditation techniques and philosophy. In addition to these, there are many schools that give themselves the - to the outsider - perplexing label of general "Grundtvigian" Folk High Schools. Use of this label entails a claim that a school is following in the footsteps of the tradition set by N. F. S. Grundtvig (1783-1872), who first proposed establishing such a school form in 1830.

Grundtvig's original vision of the folk high school was couched in both clear and compelling terms; yet his specific mandate concerning how this vision was to be realized has left many of the particulars open to debate and interpretation. And ever since the first folk high school came into existence in 1844, precisely what these schools should be doing and how they should go about doing it have been matters for continual debate, interpretation, and reinterpretation. It is not a static tradition. The very least one can say is this: a broader range of diversity could scarcely be imagined, and all of this diversity is essentially state supported.

Some people thought that there was no more need for schools like these, that they had outlived their usefulness and would most likely soon die out. People who thought that, underestimated the degree of flexibility inherent in the idea of the Folk High School, and they did not envision that the flexibility would allow the schools to respond to a different society. The Folk High School is not static. 


\section{Perspectives of the Danish Folk High Schools in the 21st Century}

In Denmark, there are more than seventy very different Folk High Schools. Over the years these schools have distinguished themselves from each other, trying to make it easier to communicate their specific goals. And they have become quite good at this. But they have also been forced to battle against a decrease in pupils applying and against cuts in support from politicians.

To survive, the schools have come together and created a single profile for the entire Danish Folk High School. With great success it seems. More pupils are signing up, and the schools are evolving in a positive direction.

The profile they could all agree on - the two things the very different schools had in common - were their academic and general purpose tracks. First they had these two tracks:

- track one: Academic skills.

- track two: Life and public awareness.

Then they applied some changes:

1. They turned life and public awareness away from a Christian National education towards civic education.

2. They reformulated both life and public awareness, giving a changed focus and a change in actual content

a. Life awareness becomes an existential perspective;

b. Public awareness becomes a political perspective.

In this, civic education and international perspectives are given a prominent position.

3. The "historical-poetical" Grundtvigian concept is preserved within this process of change.

4. The concept of competences is incorporated and the work of the Folk High Schools is focused through evaluation and documentation of its ability to give students these competences.

Finally, they developed these three tracks:

- track one: Academic skills,

- track two: Existential Perspective and Political Perspective,

- track three: Identity-related awareness, both academic and existentially. 


\section{The Contemporary Folk High School}

When the Folk High Schools were first created, Denmark was in the midst of being developed as a modern nation. Society went from being locally based to being based in the national arena. This new development resulted in a variety of initiatives, among others the folk high schools, trying to fit into this new reality of the society.

Today, a society is faced with a similar challenge, because we are moving from being based locally to being based in the global arena. Economics and politics unfold globally, but our political institutions are not made for democratic influence on a global scale. So the challenge of the Danish Society of the 21st century is this: To lift democracy up to the global level.

Grundtvig was convinced that the public had to be enlightened and educated in a way that allowed for the individual to see itself as part of the larger community. Our fundamental understanding of what defines a society is rapidly changing. We are undergoing a transition from a society defined by the nation with a fairly homogenous people and a defined territory towards a society crossing the borders of the sovereign states within economics, politics, defence, culture, environment and technology.

Today, it is not uncommon to attend Folk high School to cultivate an interest, whether it be music, sports or to prepare for a higher education.

\section{The New Challenges of today's Folk High School in Denmark}

The Danish Folk High School needs to position itself so that it becomes more than just a free space, or a sabbatical year to pupils. It needs to be a place with a holistic view on personal education, where the individual is educated through interaction with those with whom we all share our society.

The challenge is to further develop the Folk High School, so that it reflects the demographics of society even more. This means that it also needs to be able to embrace those who cannot afford education, who have no job, who have a different ethnicity or are just visiting from somewhere else.

The Folk High School is a free institution that can and should become a place where you develop new thoughts, ideas and ways of doing things through education, educational methods and efforts that are able to influence and inspire the rest of the educational sector and the Danish society and intellectual life in a wider sense. 
The folk high school must make young people address the current democratic challenges. Young people should not be met with the notion of us having the perfect democracy, but should be engaged openly with the notion of us having a need for change and rethinking of the democratic society.

In Denmark the Folk High Schools during time have faced some serious challenges, but the school form have so far managed to change it and keep the values on which the schools were build. As long as the Folk High Schools are politically supported and manage to offer interesting courses, which make sense for the people to join, the school form should be able to exist.

\section{The Universal ideas of the Folk High Schools inspired by Grundtvig}

"Man is not an ape, but a divine experiment" so Grundtvig sad almost 200 years ago, and his words still inspirers educators and politicians in Denmark and abroad. The Folk High Schools have spread all over the world, and today you can find schools in Sweden, Norway, Poland, ${ }^{1}$ Germany, Japan, India, Nigeria and the United States. The schools are all very different, and are made with inspiration from a mix of local culture and the Folk High School idea. Although you can find some ideas and aspects which are universal:

1. Learning through Living.

2. Citizenship as an aim, learning is not individual project but something we do together.

3. Combines the head (theory), the hands (practical) and the heart (feelings).

4. Combines your body and spirit.

5. Combines nature and culture.

6. Focus on self-sufficiency and sustainability.

7. Focus on the living interaction between people (equality and participatory learning).

1 The Independent Academy for Free School Teaching in Ollerup, with whom we are linked, join in Poland close relations with the Kashubian Folk High School in Wieżyca referring to the tradition of the NFS Grundtvig and Scandinavian folk high schools. For many years in Denmark we observe with great interest the activities this remarkable institution of adult education in the countries of the former "Eastern Bloc" and undertake common educational and social projects. 
8. Focus on the identity backwards and forwards (your history/ your roots - and your dreams).

9. Life awareness and happiness.

\section{Bibliography}

Ægidius K. K. (2003), Folk High School Legislation in Danemark, [in:] Byczkowski M., Maliszewski T., Przybylska E. (eds.) (2003), Folk High School - School for Life, Wieżyca: Kashubian FHS, pp. 209-213.

Egidius K. K. (2003), Fundamental Ideas and Teaching Methods - Principles in the Folk High School - Adult Education in Denmark, [in:] Byczkowski M., Maliszewski T., Przybylska E. (eds.) (2003), Folk High School - School for Life, Wieżyca: Kashubian FHS, pp. 19-31.

Ægidius K. K. (2003), School for Life Concept - Objectives, Values and Methods, [in:] Byczkowski M., Maliszewski T., Przybylska E. (eds.) (2003), Folk High School School for Life, Wieżyca: Kashubian FHS, pp. 246-248.

Allchin A. M. (1997), N.F.S. Grundtvig - An Introduction to His Life and Work, Darton: Longman and Todd.

Andresen A. (1991), The Danish Folkehøjskole today, Jelling Bogtrykkeri.

Borish S. M. (1991), The Land of the Living. The Danish folk high schools and Denmark's non-violent path to modernization, Grass Valley: Blue Dolphin.

Byczkowska S., Byczkowski M., Maliszewski T. (2002), Kaszubski Uniwersytet Ludowy u progu XXI wieku, „Oświatowiec”, nr 1(11), s. 44-64.

Byczkowska S., Maliszewski T. (2005), Scandinavian Inspirations: Looking for a True "School for Life", [in:] Maliszewski T., Wojtowicz W. J., Żerko J. (eds.), Anthology of Social and Behavioural Sciences. 20 Years of Co-operation between Universities in Linköping and Gdańsk, Linköping: Linköping University, pp. 135-147.

Byczkowski M., Maliszewski T., Przybylska E. (eds.) (2003), Folk High School School for Life, Wieżyca: Kashubian FHS.

Grundtvig N. F. S. (1991), Selected Educational Writings, Helsingør: The International People's College \& Kopenhagen: Association of Folk High Schools in Denmark.

Jurgiel A. (2003), Contemporary Concept of Folk High School as School for Life, [in:] Byczkowski M., Maliszewski T., Przybylska E. (eds.) (2003), Folk High School School for Life, Wieżyca: Kashubian FHS, pp. 249-251.

Kulich J. (2002), Grundtvig's Educational Ideas in Central and Eastern Europe and the Baltic States in Twentieth Century, Copenhagen: Forlaget Vartov.

Łowicka J. (2003), Bornholms Højskole - doświadczenia i refleksje, [w:] Byczkowski M., Maliszewski T., Przybylska E. (red.), Uniwersytet ludowy - szkoła dla życia, Wieżyca: Kaszubski Uniwersytet Ludowy im. J. Wybickiego, s. 389-392. 
Maciąg E. (2000), Raport z badań nad edukacją dorostych $w$ duńskim Uniwersytecie Ludowym - Brandbjerg Højskole, „Edukacja Dorosłych”, nr 1 (22), s. 95-104.

Maliszewski T. (2001), Uniwersytety ludowe w Polsce i w Danii: O nowy model edukacji dla dorostych, „Edukacja Dorosłych”, nr 3(28), s. 111-114.

Maliszewski T. (2002), Folk High School - School for Life. On Traditions of Adult Education in the Context of Educational Needs of the Future. [in:] Sapia-Drewniak E., Jasiński Z., Bednarczyk H. (eds.), Adult Education at the Beginning of the $21^{\text {st }}$ Century. Theoretical and Practical Contexts, Opole-Radom-Bonn: Opole University, pp. 144-153.

Maliszewski T. (2003), Development of Folk High School Idea in Denmark, Germany, Poland and Sweden. Recapitulation, [in:] Byczkowski M., Maliszewski T., Przybylska E. (eds.) (2003), Folk High School - School for Life, Wiezyca: Kashubian FHS, pp. 121-126.

Maliszewski T. (2010), Grundtvigian School for life - between Tradition and Modernity of Education on Rural Areas, "Sborník prací Pedagogické fakulty Masarykovy university, řada společenských věd”, č. 24, pp. 154-162.

Nissen G. (1994), Udfordringer til Højskolen - Danske folkehøjskoler 1844 til 1994, AiO Tryk.

Pestka S. (2003), Bornholmskie inspiracje, [w:] Byczkowski M., Maliszewski T., Przybylska E. (red.), Uniwersytet ludowy - szkoła dla życia, Wieżyca: Kaszubski Uniwersytet Ludowy im. J. Wybickiego, s. 393-399.

Solarczyk H. (2003), Z wizyta w duńskim uniwersytecie ludowym w ramach projektu UE „Uniwersytet ludowy - szkoła dla życia”, „Edukacja Dorosłych”, nr 2(35), s. 143-146.

Thoborg K. (2003), Idee uniwersytetów ludowych - Bornholm 2003, [w:] Byczkowski M., Maliszewski T., Przybylska E. (red.), Uniwersytet ludowy - szkoła dla życia, Wieżyca: Kaszubski Uniwersytet Ludowy im. J. Wybickiego, s. 306-317.

Turos L. (1983), Społeczno-wychowawcze funkcje dunskich uniwersytetów ludowych, Warszawa: Państwowe Wydawnictwo Naukowe.

Turos L. (1997), Społeczne i kulturotwórcze funkcje duńskich uniwersytetów ludowych (wybrane problemy), Warszawa: Stowarzyszenie Oświatowców Polskich - Zarząd Główny.

VodsGaard, H. J. (1997), Menneske først. Ideoploeg om højskoleånd og arbejdsliv, Middelfart: Interfolks forlag.

VodsGaard, H. J. (2000), Den sceregne højskole. Tradition og idegrundlag, Middelfart: Interfolks forlag.

VodsGaard, H. J. (2003), Højskole til tiden. De unges trang og højskolens œrinde under senmoderne vilkår, Middelfart: Interfolks forlag.

VodsGaard H. J. (2011), Dannelse, kundskaber og kompetancer. Nordplus rapport om loeringsvurdering, Middelfart: Interfolks forlag. 


\section{Webpages}

http://danishfolkhighschools.com

http://globalegrundtvig.dk

http:/uk.dfl-ollerup.dk

http://www.grundtvig.dk/hvem-er-grundtvig/who-is-grundtvig.html

http:/www.eng.uvm.dk/Education/Primary-and-Lower-Secondary-Education/Private-Schools-in-Denmark 
